\title{
STUDI META-ANALISIS METODE TOTAL PHYSICAL RESPONSE (TPR) DALAM PEMBELAJARAN BAHASA INGGRIS
}

\author{
Lia Monita ${ }^{1}$, Agung Prasetyo ${ }^{2}$ \\ ${ }^{1,2}$ Universitas Indraprasta PGRI \\ Jl. Nangka No.58 C, Jagakarsa Tanjung Barat, Jakarta Selatan \\ Corresponding Author(S): aprasetyo20@gmail.com
}

\begin{abstract}
:
Penelitian ini bertujuan untuk menganalisis efektivitas pengaruh metode Total Physical Response (TPR) pada pembelajaran bahasa Inggris. Metode penelitian yang digunakan adalah deskriptif terhadap analisis hasil publikasi penelitian ilmiah pada e-jurnal nasional. Pengaruh penelitian-penelitian yang menerapkan pembelajaran Total Physical Response (TPR) dianalisis dengan teknik meta-analisis. Temuan penelitian mengungkapkan bahwa secara keseluruhan penelitianpenelitian yang dilakukan berpengaruh dan efektif terhadap hasil belajar Bahasa Inggris peserta didik dengan effect size 0.478 atau dalam kategori efek besar. Metode Total Physical Response (TPR) pun memberikan pengaruh dan efektif dilihat dari segi jenjang pendidikan, dan penerapan pembelajaran untuk meningkatkan hasil belajar, penguasaan kosakata, dan keterampilan menyimak. Simpulan penelitian ini adalah bahwa metode Total Physical Response (TPR) lebih efektif meningkatkan kemampuan berpikir pada pelajaran Bahasa Inggris dibandingkan dengan metode pembelajaran lain dari studi ini.
\end{abstract}

\begin{abstract}
Keywords:
Total Physical

Response, teknik

meta-analisis, effect size, hasil belajar Bahasa Inggris.
\end{abstract}

\section{PENDAHULUAN}

Pada hakikatnya, bahasa termasuk Bahasa Inggris adalah alat untuk berkomunikasi diantara warga masyarakat. Berkomunikasi mengandung pengertian mengungkapkan informasi, pikiran, dan perasaan. Kegiatan komunikasi terwujud dalam tindak memahami dan mengungkapkan nuansa makna baik melalui medium lisan maupun tulisan yang dipengaruhi antara lain oleh situasi, orang yang terlibat dalam komunikasi, topik, dan kondisi psikologis orang yang terlibat dalam komunikasi. Melalui bahasa sebagai alat komunikasi utama, utamanya melalui bahasa Inggris sebagai bahasa global, kita dapat mengembangkan ilmu pengetahuan, teknologi, serta budaya dengan menggunakan bahasa tersebut. Dalam konteks pendidikan, bahasa ini berfungsi sebagai alat berkomunikasi guna mengakses, menyimpan dan berbagi informasi. Dalam keseharian, ia berfungsi sebagai alat untuk menjalin hubungan interpersonal, bertukar informasi dan menikmati aspek keindahan bahasa tersebut. 
Berpijak pada fungsinya, maka tujuan pengajaran Mata Pelajaran Bahasa Inggris dalam Kurikulum yang berlaku saat ini mencakup: (1) Mengembangkan kemampuan berkomunikasi dalam bahasa tersebut baik lisan maupun tulis. Kemampuan tersebut meliputi menyimak (listening), berbicara (speaking), membaca (reading), dan menulis (writing); (2) Menumbuhkan kesadaran akan hakikat dan pentingnya bahasa Inggris sebagai salah satu bahasa asing untuk menjadi alat utama belajar; (3) mengembangkan pemahaman keterkaitan antara bahasa dan budaya serta memperluas cakrawala budaya. Dengan demikian siswa memiliki wawasan lintas budaya dan melibatkan diri dalam keragaman budaya.

Untuk mencapai tujuan pengajaran Mata Pelajaran Bahasa Inggris diperlukan saling keterkaitan antar komponen dalam kurikulum, yakni tujuan pengajaran yang dalam konteks kurikulum saat ini dan sejalan dengan Standar Isi yang diatur dalam Peraturan Pemerintah No.19, dinyatakan dalam bentuk rumusan standar kompetensi dan kompetensi dasar yang selanjutnya dirumuskan secara spesifik dalam bentuk indikator yang digunakan sebagai bahan pertimbangan dalam memilih dan mengembangkan komponen kurikulum lainnya, yakni bahan ajar, kegiatan pemelajaran, dan evaluasi pemelajaran. Keempat komponen utama kurikulum ini dalam Kurikulum Mata Pelajaran Bahasa Inggris yang berlaku saat ini harus secara eksplisit dicakup dalam silabus mata pelajaran Bahasa Inggris yang dikembangkan baik untuk kepentingan pemelajaran di kelas maupun untuk pengembangan bahan ajar. Dalam petunjuk guru ini keempat komponen tersebut dicoba dipetakan dengan mengacu kepada kurikulum tersebut.

Belajar Bahasa Inggris dirasakan hanya sebagai salah satu mata pelajaran yang menuntut siswa untuk memilki nilai baik tanpa berfikir bahwa bahasa itu adalah sebuah skill yang harus mereka kuasai dan pahami, mereka pun belum menyadari bahwa mengaplikasikan bahasa Inggris sebenarnya tidak jauh berbeda dengan bahasa Indonesia sendiri sehingga materi yang telah dipelajari mudah dilupakan dan tidak bermakna bagi siswa. Akibatnya semakin tinggi jenjang pendidikan, semakin tinggi materi pembelajaran Bahasa Inggris, semakin sulit bagi siswa untuk memahami Bahasa Inggris.

Mengingat bahwa setiap pembelajaran bahasa merupakan pekerjaan yang rumit karena melibatkan banyak faktor, hal tersebut dibagi menjadi: motivasi, kondisi dan suasana tempat belajar, metode pengajaran dan kompetensi guru. Penelitian ini akan menganalisis salah satu metode pembelajaran yaitu metode TPR (Total Physical Response) yang banyak diterapkan oleh para peneliti tentang pengaruhnya terhadap berbagai keterampilan berbahasa.

Metode Total Physical Response (TPR) ini mendasarkan diri pada pemahaman tentang potensi fungsi otak kanan dan otak kiri. Aktivitas motorik yang merupakan fungsi otak sebelah kiri. Dengan penggunaan metode ini pada pelajaran bahasa Inggris diharapkan dapat meningkatkan hasil belajar siswa dan menyebabkan siswa tidak lagi merasa bosan dan terpaksa dalam mengikuti pelajaran bahasa Inggris, akan tetapi karena itu adalah kebutuhannya yang harus dipelajarinya dengan baik.

Menurut Ahmad Izzan (2010: 68), teknik meta-analisis merupakan metode statistik untuk menggabungkan hasil kuantitatif dari beberapa penelitian untuk menghasilkan rangkuman secara keseluruhan atas pengetahuan empiris pada topik tertentu. Hal ini 
digunakan untuk menganalisis kecenderungan sentral dan variasi dalam hasil studi. Pada penelitian ini, peneliti akan menggunakan beberapa sampel berupa penelitian terdahulu dengan topik sejenis untuk memperoleh informasi dan dapat dianalisis besar pengaruh pada studi terdahulu.

Terdapat beberapa penelitian meta-analisis, seperti yang telah dilakukan oleh Melek Damirel dan Miray Dagyar (2016) di Turki mengenai studi meta- analisis terhadap 47 studi tentang efek pembelajaran berdasarkan masalah pada sikap menunjukkan hasil positif dalam hal peningkatan sikap, namun besar pengaruh yang diperoleh dalam kategori rendah dengan harga 0.44 pada ketentuan Hedges dari jenjang Taman KanakKanak sampai jenjang Perguruan Tinggi. Indri Anugraheni (2018) memaparkan hasil meta-analisis model pembelajaran Problem Based Learning dalam meningkatkan keterampilan berpikir kritis di Sekolah Dasar terhadap 23 artikel penelitian bahwa model tersebut mampu meningkatkan kemampuan berpikir peserta didik mulai dari yang terendah $2.87 \%$ sampai yang tertinggi $33.56 \%$ dengan rata-rata $12.73 \%$. Sedangkan pada studi lain, Kadir (2014) mengungkapkan tentang meta-analisis pada efektivitas penerapan pendekatan problem solving dalam pembelajaran sains dan matematika bahwa memiliki pengaruh yang besar dengan harga besar pengaruh 1.079.

Beberapa penelitian meta-analisis yang telah dilakukan tersebut secara keseluruhan belum fokus pada bidang kajian Bahasa Inggris, belum ada penelitian meta- analisis terbaru mengenai pembelajaran Total Physical Response (TPR) pada pembelajaran Bahasa Inggris.

\section{METODE}

\section{Metode Penelitian}

Metode penelitian yang digunakan adalah penelitian deskriptif, yaitu analisis menyajikan hasil publikasi penelitian ilmiah tentang pengaruh metode Total Physical Response (TPR) pada pembelajaran bahasa Inggris. Iskandar (2013), menjelaskan bahwa penelitian deskriptif merupakan penelitian untuk memberi uraian mengenai fenomena atau gejala sosial yang diteliti dengan mendeskripsikan tentang nilai variabel mandiri, baik satu variabel atau lebih (independent) berdasarkan indikator-indikator dari variabel yang diteliti guna untuk eksplorasi dan klasifikasi dengan mendeskripsikan sejumlah variabel yang berkenaan ini tidak sampai mempersoalkan asosiatif dan komparatif antara variabelvariabel penelitian yang ada.

\section{Populasi dan Sampel}

Sugiyono (2017), menjelaskan bahwa populasi adalah wilayah generalisasi yang terdiri atas: obyek/subyek yang mempunyai kualitas dan karakteristik tertentu yang ditetapkan oleh peneliti untuk dipelajari dan kemudian ditarik kesimpulannya. Sedangkan Iskandar (2013), menjelaskan bahwa sampel adalah sebagian dari populasi yang diambil secara representatif atau mewakili populasi yang bersangkutan atau bagian kecil yang diamati. Penelitian terhadap sampel biasanya disebut studi sampling.

Populasi dalam penelitian ini adalah artikel publikasi ilmiah berupa jurnal berskala nasional di Indonesia tentang metode Total Physical Response (TPR) tahun 2013-2020. Sampel yang diambil adalah artikel publikasi ilmiah tentang pembelajaran Total Physical Response (TPR) pada konsep materi Bahasa Inggris dengan kategori jenis penelitian 
sebagai berikut, yaitu: (1) Artikel dibuat oleh peneliti umum maupun mahasiswa; (2) artikel menggunakan metode penelitian eksperimen; (3) artikel merupakan penelitian kuantitatif dan memenuhi data statistik effcet size; (4) artikel diterbitkan 7 tahun terakhir yaitu tahun 2013-2020; (5) artikel bertema pembelajaran Total Physical Response (TPR) pada konsep materi Bahasa Inggris; (6) sampel jenjang pendidikan pada artikel merupakan pada jenjang Taman Kanak-kanak (TK); Sekolah Dasar (SD); dan Sekolah Menengah Pertama (SMP).

\section{Teknik Analisis Data}

Unit dasar studi meta-analisis adalah Effect Size, maka untuk menjawab rumusan masalah penelitian digunakan perhitungan dengan teknik analisis besaran pengaruh (effect size).

Menurut Borenstein, dkk (2009: 3-4), menjelaskan bahwa Effect size adalah nilai yang mencerminkan besarnya efek dari sebuah perlakuan (lebih umumnya) kekuatan antara dua variabel, ini merupakan kesatuan dalam meta-analisis. Menghitung effect size untuk setiap studi, untuk menilai konsistensi efek pada seluruh studi dan menghitung efek ringkasannya.

Piggot (2012: 7-11) mengutarakan bahwa terdapat tiga jenis dasar Effect Size, yaitu: standardized mean difference, correlation coeficient, dan log odd ratio. Standardized mean difference adalah bentuk paling umum dari effect size ketika penelitian terfokus antara dua kelompok independen seperti kelompok perlakuan dan kontrol. Correlation coeficient biasanya digunakan ketika sintesis studi observasional, ketika question penelitian berkaitan dengan memperkirakan kekuatan hubungan (asosiasi) antara dua ukuran. Log odd ratio dapat dihitung untuk membandingkan asumsi antara dua kelompok.

Formula Effect Size yang digunakana adalah formula eta-square $\left(\eta^{2}\right)$ berikut:

Menurut Kadir (2017), menjelaskan bahwa penelitian eksperimen yang hanya melibatkan dua kelompok, yaitu kelompok eksperimen dan kelompok kontrol, menggunakan analisis komparasi dengan teknik analisis uji-t. Maka menggunakan formula effect size sebagai berikut:

$\eta^{2}=r^{2}=\frac{t_{o^{2}}}{t_{o^{2}}+d b}$

Untuk penelitian eksperimen melibatkan lebih dari dua kelompok, menggunakan analisis komparasi dengan teknik analisis Anova-1 Jalan, dengan formula sebagai berikut:

$$
\eta^{2}=\frac{J K_{\text {antara }}}{J K_{\text {total }}}
$$

Menurut Kadir (2017: 165), menjelaskan bahwa penelitian eksperimen yang melibatkan lebih dari dua kelompok dan interaksinya, menggunakan analisis komparasi dengan teknik analisis Anova-2 Jalan, maka formula yang digunakan sebagai berikut:

$\eta^{2}{ }_{\mathrm{A}}=\frac{\mathrm{JK}(\mathrm{A})}{\mathrm{JK}(\mathrm{A})+\mathrm{JK}(\mathrm{D})}$

$\eta^{2}{ }_{\mathrm{B}}=\frac{\mathrm{JK}(\mathrm{B})}{\mathrm{JK}(\mathrm{B})+\mathrm{JK}(\mathrm{D})}$

$\eta^{2}{ }_{\mathrm{AXB}}=\frac{\mathrm{JK}(\mathrm{AB})}{\mathrm{JK}(\mathrm{AB})+\mathrm{JK}(\mathrm{D})}$ 
Glass (2012: 6), menjelaskan bahwa penelitian eksperimen dengan asumsi kelompok heterogen dua kelompok formula yang digunakan yaitu:

$\Delta=\frac{\mathrm{X}_{\mathrm{E}}-\mathrm{X}_{\mathrm{K}}}{\mathrm{S}_{\mathrm{K}}}$

Kriteria yang digunakan untuk membentuk interpretasi hasil effect size, yaitu:

Efek kecil $\quad: 0.01<\eta^{2} \leq 0.09$

Efek sedang : $0.09<\eta^{2} \leq 0.25$

Efek besar : $\quad \eta^{2}>0.25$

\section{HASIL DAN PEMBAHASAN}

Data besar pengaruh (effect size) artikel publikasi ilmiah pembelajaran Total Physical Response (TPR) berdasarkan kategori terdiri dari tiga kriteria yaitu efek kecil $\left(0.01<\eta^{2}\right.$ $\leq 0.09)$, efek sedang $\left(0.09<\eta^{2} \leq 0.25\right)$ dan efek besar $\left(\eta^{2}>0.25\right)$ dapat dilihat pada Tabel berikut:

Tabel 1 Effect Size Berdasarkan Kategori

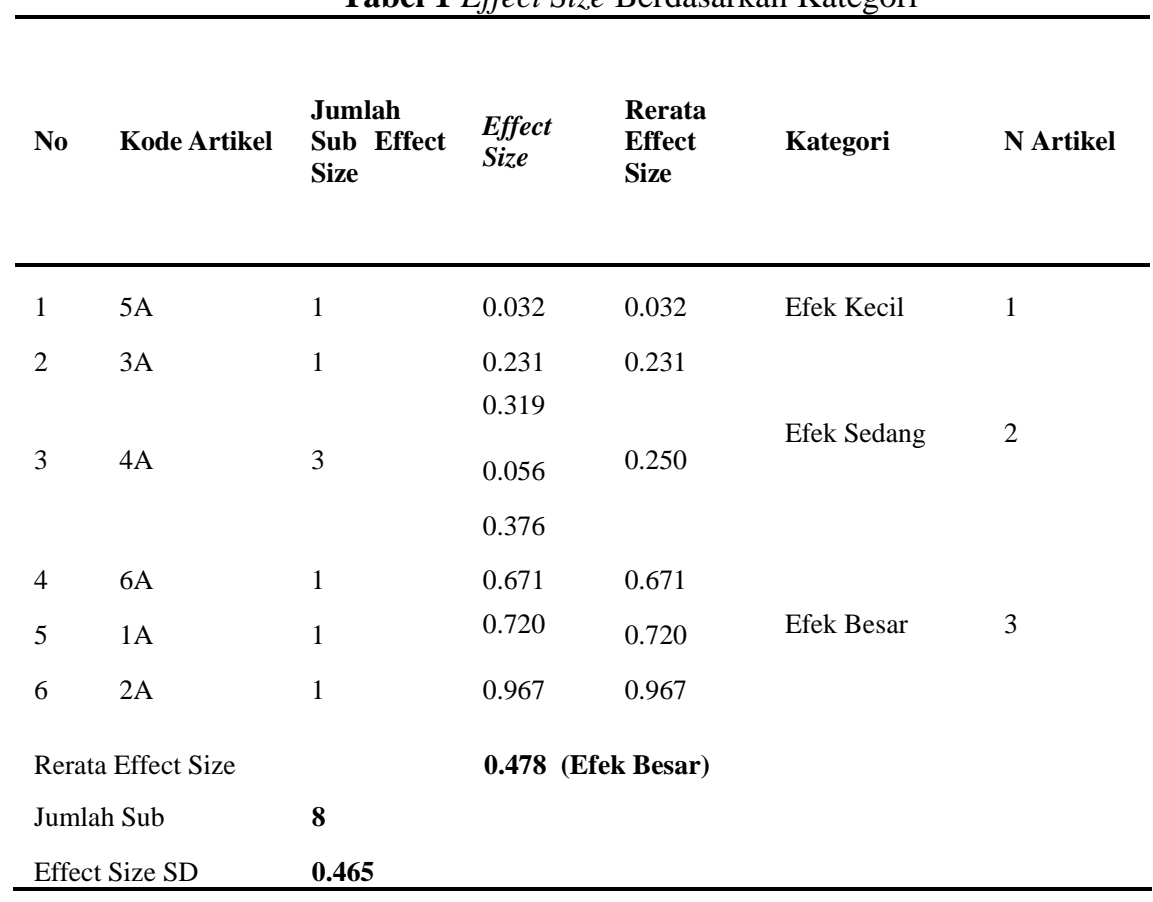

Hasil data analisis pada Tabel 1 menunjukkan bahwa terdapat satu artikel publikasi ilmiah dengan effect size kecil, dua artikel publikasi ilmiah dengan effect size sedang, dan tiga artikel publikasi ilmiah dengan effect size besar. Dari perhitungan diatas diperoleh effect size keseluruhan sebesar 0.478 dalam kategori efek besar dan simpangan baku sebesar 0.465, hal tersebut dapat disimpulkan bahwa metode Total Physical Response (TPR) memiliki pengaruh besar pada pembelajaran bahasa Inggris.

Jenjang pendidikan menjadi salah satu aspek yang dapat dianalisis yaitu terdiri dari Taman Kanak-kanak (TK), Sekolah Dasar (SD), dan Sekolah Menengah Pertama (SMP). Data hasil effect size pembelajaran Total Physical Response (TPR) pada pembelajaran Bahasa Inggris berdasarkan jenjang pendidikan dapat dilihat pada Tabel berikut: 
Tabel 2 Effect Size Berdasarkan Jenjang Pendidikan

\begin{tabular}{ccccc}
\hline No & $\begin{array}{c}\text { Jenjang } \\
\text { Pendidikan }\end{array}$ & N Artikel & Effect Size & SD \\
\hline 1 & TK & 2 & 0.608 & 0.611 \\
2 & SD & 3 & 0.328 & 0.307 \\
3 & SMP & 1 & 0.671 & - \\
\hline
\end{tabular}

Dari tabel diatas menunjukkan bahwa besar pengaruh pada ketiga jenjang pendidikan tersebut pada Taman Kanak-kanak (TK) memiliki effect size sebesar 0.608, pada Sekolah Dasar (SD) memiliki effect size sebesar 0.328, dan pada_Sekolah Menengah Pertama (SMP) memiliki effect size sebesar 0.671. Dari_pernyataan diatas dapat disimpulkan bahwa Jenjang Pendidikan Menengah Pertama (SMP) memiliki pengaruh tertinggi terhadap pembelajaran dengan menggunakan metode Total Physical Response (TPR) dengan effect size sebasar 0.671, dan temuan ini mengungkapkan bahwa jenjang Pendidikan Menengah Pertama (SMP) tersebut paling efektif bila diterapkan pada siswa, walaupun pengaruh tertinggi tersebut memiliki data yang sangat bervariasi.

Data hasil effcet size berdasarkan variabel terikat penelitian dalam pembelajaran dengan menggunakan metode Total Physical Response (TPR) pada pembelajaran Bahasa Inggris dapat dilihat pada Tabel 3 berikut:

Tabel 3 Effect Size Berdasarkan Variabel Terikat Penelitian

\begin{tabular}{ccccc}
\hline & & & & \\
No & $\begin{array}{c}\text { Variabel Terikat } \\
\text { Penelitian }\end{array}$ & N Artikel & Effect Size & SD \\
\hline 1 & Hasil Belajar & 2 & 0.475 & 0.404 \\
2 & Penguasaan Kosakata & 3 & 0.420 & 0.349 \\
3 & Keterampilan Menyimak & 2 & 0.451 & 0.380 \\
\hline
\end{tabular}

Pada tabel 3 artikel publikasi ilmiah menampilkan penelitian tentang variabel terikat penelitian mengenai penerapan pengajaran berupa output yang diharapkan yaitu hasil belajar dengan effect size sebesar 0.475 yang memiliki dua artikel publikasi ilmiah, pada penguasaan kosakata dengan effect size sebesar 0.420 yang memiliki tiga artikel publikasi ilmiah, dan pada keterampilan menyimak dengan effect size sebesar 0.451 yang memiliki dua satu artikel penelitian.Dari pernyataan diatas dapat disimpulkan bahwa metode Total Physical Response (TPR) memiliki pengarauh besar pada hasil belajar dengan effect size sebesar 0.475

\section{SIMPULAN}

Secara keseluruhan pembelajaran dengan menggunakan metode Total Physical Response (TPR) mampu meningkatkan hasil belajar Bahasa Inggris peserta didik pada kelompok eksperimen dengan besar pengaruh (effect size) 0.478. Hal tersebut menunjukkan bahwa pembelajaran Total Physical Response (TPR) memberikan pengaruh yang lebih efektif 
dan metode pembelajaran Total Physical Response (TPR) layak digunakan dalam pembelajaran Bahasa Inggris. Metode pembelajaran Total Physical Response (TPR) merupakan alternatif pembelajaran untuk meningkatkan hasil belajar Bahasa Inggris.

Secara variabel terkait pembelajaran dengan menggunakan Total Physical response (TPR) mampu meningkatkan hasil belajar peserta didik dengan hasil effect size sebesar 0.475 , penguasaan kosakata dengan hasil effect size sebesar 0.420 , dan ketampilan menyimak dengan hasil effect size sebesar 0.451 .

Besar pengaruh pembelajaran dengan menggunakan Total Physical Response (TPR). berdasarkan jenjang pendidikan mampu meningkatkan hasil belajar peserta didik baik tingkat Taman Kanak-kanak (TK) dengan hasil effect size sebesar 0.608, Sekolah Dasar (SD) dengan hasil effect size sebesar 0.328, dan Sekolah Menengah Pertama (SMP) dengan hasil effect size sebesar 0.671 .

\section{REFERENSI}

Izzan, A. (2010). Metodologi pembelajaran bahasa inggris, Bandung: Humaniora. Iskandar. (2013). Metodologi penelitian pendidikan dan sosial. Ciputat: Referensi. Sugiyono. (2017). Metode penelitian pendidikan: Pendekatan kuantitatif, kualitatif dan $R \& D$. Bandung: Alfabeta.

Borenstein, M., Larry V. H., Julian P.T., Higgins, Hannah, R. R. (2009). Introduction to Meta-analysis. United Kingdom: John Wiley and Sons Publication. 2009.

Piggot, T. D. (2012). Advances in meta-analuysis: Statistics for social and behavioral sciences. USA: Springer.

Kadir. (2017). Meta-analysis of the effect of learning intervention toward mathematical thinking on research and publication of students. Tarbiya: Journal of Education in Muslim Society.

Glass. (2012). Meta-analysis of research on class size and achievement. Jstore, 1(1).

\section{APPENDIX}

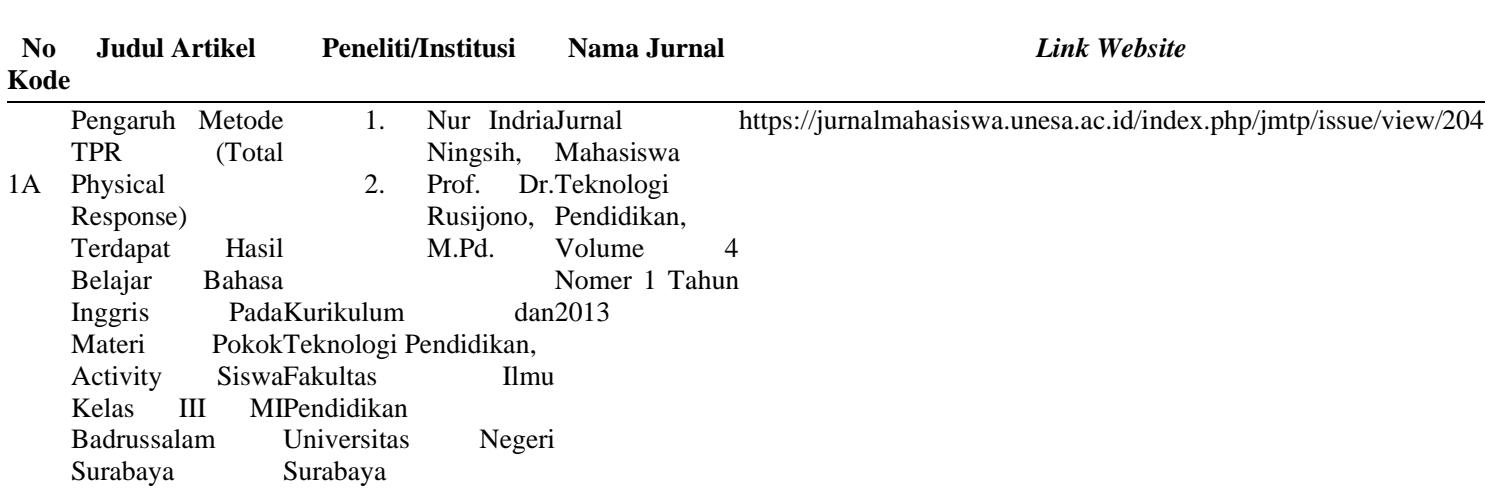


PENGARUH 1. Ni Luh Suantari Jurnal https://ejournal.undiksha.ac.id/index.php/JJPAUD METODE TOTAL 2. Putu AdityaPendidikan PHYSICAL RESPONSE TERHADAP Antara Anak Usia Din

2A KEMAMPUAN KOSAKATA Putu RahayuUndiksha Pendidikanp-ISSN : 2613 9669; e-ISSN

INGGRIS Universitas Pendidikan2613-9650 ANAK Ganesha Singaraja,

KELOMPOK B Indonesia

PENGARUH

METODE TOTALDian Hartini

PHYSICAL

RESPONSE JURUSAN

3A TERHADAP PENDIDIKAN GURU

HASIL BELAJARMADRASAH

SISWA PADAIBTIDAIYAH (PGMI)

MATA FAKULTAS

PELAJARAN TARBIYAH DANSkripsi, 2018

BAHASA KEGURUAN

INGGRIS DIUNIVERSITAS

KELAS III MIISLAM NEGERI (UIN)

NURUL ISLAMMATARAM

SEKARBELA

TAHUN

PELAJARAN

2017/2018

PENGARUH Aida Fitriyani

METODE TOTALKhusniyati

PHYSICAL

4A RESPONSE

BERBANTUAN PROGRAM STUDI

MEDIA FLASHPENDIDIKAN DASAR

CARD KONSENTRASI

TERHADAP PENDIDIKAN ANAK

KEMAMPUAN USIA DINI Skripsi, 2020

MENYIMAK PASCASARJANA

DAN UNIVERSITAS

PENGUASAAN NEGERI SEMARANG

KOSAKATA

BAHASA

INGGRIS

PADA ANAK

USIA DINI

EFEKTIVITAS

PENERAPAN

METODE TOTAL Wini Citra Lestari,Agustus 2014
PHYSICAL Yusuf

RESPONSE Hidayat

WITH PICTURES

5A TERHADAP

PROGRAM S-I

PENGUASAAN UNIVERSITAS

KOSAKATA PENDIDIKAN

BAHASA INDONESIA

INGGRIS SISWA KAMPUS

TASIKMALAYA 
Mengajar

Listening

Menggunakan

Video Kartun dan

TPR

Untuk Sekolah

6A Menengah

Pertama
Vol. 2 No. 1

Februari 2020

eISSN 2716-

1. Riyan

Maulana

2. Rahmad

Muliana

jurnal.stmikiba.ac.id

Dosen STMIK

Indonesia Banda Aceh 